\title{
MEDIA FLASHCARDS SEBAGAI MEDIA PEMBELAJARAN BAHASA ARAB YANG EFEKTIFUNTUK MENINGKATKAN PERBENDAHARAAN KOSAKATA SISWA
}

\author{
Widi Astuti \\ Dosen STAIMS Yogyakarta
}

\begin{abstract}
The purpose of this study is to explain the importance of instructional media in improving students' vocabulary in Arabic. Learning media has an urgent position in the delivery of the material in order to understand the students. The presence of media in the midst of learning activities is certainly a positive impact on students in learning and increase students' vocabulary in Arabic, so that by the learning media teaching and learning activities to be effective, innovative and learning atmosphere is not monotonous. This type of research used in this research is a case study which is then understood in depth to describe holistically and comprehensively about the symptoms and events in conducting this study. The discussion in this paper, among others, the media are learning Arabic Flashcards media (picture card media) in terms of the characteristics, functions, usage and advantages in improving students' vocabulary in Arabic.
\end{abstract}

Keywords: Media Flashcards, vocabulary Arabic

\begin{abstract}
Abstrak
Tujuan dari penelitian ini adalah untuk menjelaskan pentingnya media pembelajaran dalam meningkatkan perbendaharaan kosakata bahasa Arab siswa. Media pembelajaran mempunyai posisi yang urgen dalam penyampaian materi agar dapat dipahami siswa. Kehadiran media ditengah-tengah kegiatan belajar mengajar tentunya membawa dampak positif bagi siswa dalam mempelajari dan menambah perbendaharaan kosakata bahasa Arab siswa, sehingga dengan adanya media pembelajaran kegiatan belajar mengajar menjadi efektif, inovatif dan suasana belajar tidak monoton. Jenis penelitian yang digunakan dalam penelitian ini adalah penelitian studi kasus yang kemudian dipahami secara mendalam untuk mendeskripsikan secara holistic dan komperhensif tentang gejala dan peristiwa dalam melaksanakan penelitian ini. Adapun pembahasan dalam tulisan ini antara lain mengenai media pembelajaran bahasa Arab yaitu media Flashcards (media kartu bergambar) ditinjau dari karakteristik, fungsi, penggunaan dan kelebihannya dalam meningkatkan perbendaharaan kosakata bahasa Arab siswa.

Kata kunci: Media Flashcards, perbendaharaan kosakata bahasa Arab.
\end{abstract}

\section{A. PENDAHULUAN}

Kosakata merupakan hal yang sangat mendasar bila seseorang ingin mempelajari bahasa asing (bahasa Arab), dengan kosakata yang dikuasai maka seseorang akan dengan mudah dalam memahami bahasa Asing. Seiring dengan berkembangnya ilmu pengetahuan, bahasa Arab kini semakin eksis didalam dunia pendidikan, bahasa Arab kini tidak hanya menjadi salah satu muatan lokal dalam materi pembelajaran baik pada jenjang Pendidikan Sekolah Dasar, Menengah dan Lanjutan. 
Namun, pada kenyataannya tidak sedikit siswa yang belum mampu menguasai bahasa Arab secara maksimal, hal ini ditandai dengan rendahnya kosakata yang dimiliki, sebab tidak semua siswa mempunyai latarbelakang pendidikan yang mendukung didalam pembelajaran bahasa Arab. Selain faktor tersebut peran guru juga sangat penting dan berpengaruh dalam proses belajar mengajar, dengan adanya peran aktif guru dalam menghadirkan strategi, metode dan media yang inovatif maka materi akan tersampaikan dengan mudah. Persoalan yang merupakan kendala disini adalah guru belum mampu menghadirkan media untuk menunjang pendidikan siswa dalam pembelajaran bahasa Arab khususnya dengan tujuan meningkatkan kosakata siswa, masalah ini dilatarbelakangi dengan penyediaan media akan membutuhkan biaya dan waktu yang cukup besar, dalam hal ini guru tidak mau mengambil resiko yang menjadikan pembelajaran bahasa menjadi monoton dan membosankan sehingga proses belajar mengajar berjalan tidak efektif dan siswa sulit dalam menyerap apa yang disampaikan guru yang berakibat pada pemerolehan belajar bahasa siswa yang rendah.

Adapun banyak penelitian yang telah membuktikan keefektifan penggunaan media dalam pembelajaran bahasa Asing (bahasa Arab), namun tidak banyak guru yang menggunakan media pembelajaran di sekolah, sebagaimana disebutkan Suyanto diatas dan diungkapkan pula oleh Robert Gagne yang menyebutkan bahwa media sebagai komponen sumber belajar yang dapat merangsang untuk belajar, Gagne disebut sebagai aliran modern NeoBehaviorism yang mendorong guru untuk merencanakan pembelajaran agar suasana dan gaya belajar dapat dimodifikasi.

Uraian diatas jelas menerangkan bahwa terdapat kesenjangan antara kondisi ideal dengan kondisi yang ada atau nyata bahwa media sangatlah berpengaruh didalam menciptakan suasana belajar yang menarik dan menyenangkan sehingga siswa akan dengan mudah menerima informasi atau ilmu dari materi yang disampaikan guru didalam proses belajar mengajar bahasa Arab. Berdasarkan permasalahan tersebut, tulisan ini berusaha untuk memberi penjelasan tentang media flashcards sebagai media pembelajaran bahasa Arab yang efektif dalam meningkatkan perbendaharaan kosakata siswa. 


\section{B. PEMBAHASAN}

Pembelajaran bahasa merupakan suatu sistem yang melibatkan banyak komponen. Komponen-komponen tersebut saling kait mengkait dan mempengaruhi berhasil atau tidaknya proses pembelajaran bahasa. Diantara komponen-komponen itu adalah tujuan, materi, metode, sumber belajar, media pembelajaran, interaksi belajar-mengajar, evaluasi hasil belajar, pembelajar, atau siswa dan guru. Setiap guru harus menguasai komponenkomponen tersebut dan terampil menerapkannya dalam proses belajar mengajar, ${ }^{1}$ sehingga dapat menghasilkan proses belajar mengajar yang berkualitas. Sedangkan tujuan dari belajar mengajar berfungsi menentukan ke arah mana subyek didik akan dibawa. ${ }^{2}$

Faktor-faktor yang sangat esensial dalam proses belajar-mengajar adalah metode belajar mengajar yang digunakan. Berdasarkan pandangan yang merujuk kepada teoriteori yang ada, maka metode-metode belajar mengajar, termasuk metode belajar mengajar bahasa Arab harus dipilih yang dapat memberikan rangsangan (stimulus) siswa untuk belajar (teori behavioristik), mengembangkan kemampuan perseptual kognitifnya dan mengkonstruksi sendiri pengetahuan yang ingin dipelajari (teori kognitif), serta menghargai siswa sebagai pribadi yang unik (teori humanistik). ${ }^{3}$

Adapun proses belajar mengajar, seorang guru memiliki tugas dan peran yang sangat sentral. Sukses atau tidaknya serta bermutunya atau tidaknya proses belajar mengajar sangat tergantung pada pribadi guru. Mengingat pentingnya peran guru dalam proses belajar mengajar, para ahli pendidikan telah merumuskan berbagai tugas dan peran yang harus dimainkan oleh para guru.

Kata "media" berasal dari bahasa Latin dan merupakan bentuk jama' dari kata medium yang secara terminologi berarti perantara atau pengantar. ${ }^{4}$ Sedangkan dalam bahasa Arab media berasal dari kata wasaaila artinya perantara atau pengantar pesan dari

\footnotetext{
${ }^{1}$ Hendyat Soetopo, pendidikan dan pembelajaran, teori, permasalahan, dan praktek, (Malang: UMM Press, 2005), hal. 143.

${ }^{2}$ Amir Daien Indrakusuma, Pengantar Ilmu Pendidikan, (surabaya: usaha Nasional, 1973), hal.44.

${ }^{3}$ Syamsuddin Asyrofi, dkk, Metodologi Pembelajaran bahasa Arab, (yogyakarta: Pokja Akademik, 2006), hal. 25.

${ }^{4}$ Arif S. Sadirman,Media pendidikan : pengertian, pengembangan, dan pemanfaatannya, （ Jakarta: Rajawali, 1990), hal. 6.
} 
pengirim ke penerima pesan. ${ }^{5}$ Namun pada intinya, media pembelajaran adalah segala sesuatu yang menyangkut software ataupun hardware yang dapat digunakan untuk menyampaikan isi materi ajar dari sumber belajar ke pebelajar (individu atau kelompok), yang dapat merangsang pikiran, perasaan, perhatian dan minat pebelajar sedemikian rupa sehingga proses belajar (di dalam atau di luar kelas) menjadi lebih efektif.

Berdasarkan awal perkembangannya, media memiliki posisi sebagai alat bantu dalam kegiatan pembelajaran, yaitu alat bantu mengajar bagi guru (teaching aids). Media sebagai alat bantu dalam mengajar diharapkan dapat memberikan pengalaman kongkret, motivasi belajar, mempertinggi daya serap dan retensi belajar siswa. ${ }^{6}$ Seiring dengan kemajuan tekhnologi di berbagai bidang, misalnya dalam tekhnologi komunikasi dan informasi pada saat ini, media pembelajaran memiliki posisi sentral dalam proses belajar dan bukan semata-mata sebagai alat bantu. Media adalah bagian integral dari proses belajar mengajar, dalam posisi seperti ini, penggunaan media pembelajaran dikaitkan dengan apa-apa saja yang dapat dilakukan oleh media, yang mungkin tidak mampu dilakukan oleh guru (atau guru melakukannya kurang efisien). Dengan kata lain, bahwa posisi guru sebagai fasilitator dan media memiliki posisi sebagai sumber belajar yang menyangkut keseluruhan lingkungan disekitar pebelajar.

Ditinjau dari segi penggunaan media dikaitkan dengan indera yang digunakan manusia untuk memperoleh pengetahuan, media diklasifikasikan menjadi tiga macam, yaitu:

a. Media Bashariyah ( media pandang/ visual)

Media visual dapat berupa alat peraga yaitu; benda-benda alamiah, orang, dan kejadian; tiruan benda-benda alamiah, orang dan kejadian; dan gambar benda-benda alamiah, orang dan kejadian.

Media pandang lainnya adalah kartu dengan segala bentuknya, yang meliputi: 1) kartu huruf, 2) kartu kata, 3) kartu kalimat, serta 4) kartu gambar.

${ }^{5}$ Abdul Hamid, dkk, Pembelajaran bahasa Arab: Matode, Strategi, Materi, dan Media, $\quad$ ( Malang: UIN Malang Press, 2010), hal. 168.

${ }^{6}$ Aswan Zain dan Syaiful Bahri Djamarah,Strategi Belajar mengajar (Jakarta : PT Rineka Cipta, 1995),hal. 136. 
Adapun dalam konteks pembelajaran bahasa Arab, benda-benda tiruan dan gambar merupakan media yang cukup efektif untuk digunakan, terutama untuk pengenalan mufrodat dan pola kalimat.

Penggunaan media dalam pengajaran bahasa bertitik tolak dari teori yang mengatakan bahwa totalitas persentase banyaknya ilmu pengetahuan, ketrampilan, dan sikap yang dimiliki oleh seseorang terbanyak dan tertinggi melalui indra lihat dan pengalaman langsung melakukan sendiri, sedangkan selebihnya melalui indera dengar dan indra lainnya. John M. Lannon mengemukakan bahwa media pengajaran khususnya alat-alat pandang dapat:

1) Menarik minat siswa;

2) Meningkatkan pengertian siswa;

3) Memberikan data yang kuat/ terpercaya;

4) Memadatkan informasi;

5) Memudahkan menafsirkan data.

Selain itu, media pengajaran juga dapat membagkitkan motivasi belajar serta memberikan stimulus bagi kemauan belajar. Hal ini seiring dengan apa yang dikemukakan oleh Prof. Mahmud Yunus bahwasannya media pengajaran itu berpengaruh besar bagi indera dan lebih memudahkan (dapat menjamin) pemahaman karena orang yang melihat tidak sama dengan orang yang hanya mendengar.

b. Media sam'iyah ( dengar/ audio)

Media audio yang dapat digunakan untuk pengajaran bahasa antara lain radio, tape recorder, dan laboratorium bahasa.

c. Media Sam'iyyah-Bashariyah (dengar-pandang / Audio Visual)

Media pengajaran bahasa yang paling lengkap adalah media audiovisual, karena dengan media ini terjadi proses saling membantu antara indera dengar dan indera pandang. Yang termasuk media ini adalah televisi, VCD, Komputer dan Lab.

Nana Sudjana merumuskan fungsi media pengajaran menjadi 6 kategori, sebagai berikut:

1) Penggunaan media dalam proses belajar mengajar bukan merupakan fungsi tambahan, tetapi mempunyai fungsi sendiri sebagai alat bantu untuk mewujudkan situasi belajar mengajar yang efektif. 
2) Penggunaan media pengajaran merupakan bagian integral dari keseluruhan situasi mengajar. Ini berarti bahwa media pengajaran merupakan salahsatu unsur yang harus dikembangkan guru.

3) Media pengajaran dalam pengajaran, penggunaannya integral dengan tujuan dari isi pelajaran. Fungsi ini mengandung pengertian bahwa penggunaan (pemanfaatan media harus melihat kepada tujuan dan bahan pelajaran.

4) Penggunaan media dalam pengajaran bukan semata-mata alat hiburan, dalam arti digunakan hanya sekedar melengkapi proses belajar supaya lebih menarik perhatian siswa.

5) Penggunaan media dalam pengajaran lebih diutamakan unutk mempercepat proses belajar mengajar dan membantu siswa dalam menangkap pengertian yang diberikan guru.

6) Penggunaan media dalam pengajaran diutamakan untuk mempertinggi mutu belajar mengajar. Dengan perkataan lain, menggunakan media, hasil belajar yang dicapai siswa akan tahan lama diingat siswa, sehingga pelajaran mempunyai nilai tinggi.

Berdasarkan atas beberapa fungsi media pembelajaran oleh para ahli, dapat disimpulkan bahwa penggunaan media dalam kegiatan belajar mengajar memiliki pengaruh yang besar terhadap alat-alat indera. Penggunaan media akan lebih menjamin terjadinya pemahaman dan retensi yang lebih baik terhadap isi pelajaran. Dengan aneka macam bentuk dan jenis media pembelajaran yang digunakan oleh guru menjadi sumber ilmu pengetahuan bagi siswa. Dalam menerangkan suatu benda, guru dapat membawa bendanya secara langsung kehadapan siswa di kelas. Dengan menghadirkan bendanya seiring dengan penjelasan mengenai benda itu dijadikan sebagai sumber belajar.

Media pembelajaran juga mampu membangkitkan dan membawa pembelajar ke dalam suasana rasa senang dan gembira, dimana ada keterlibatan emosional dan mental. Tentu hal ini berpengaruh terhadap semangat mereka belajar dan kondisi pembelajaran yang lebih "hidup", yang nantinya bermuara kepada peningkatan pemahaman pebelajar terhadap materi ajar. Jadi, sasaran akhir penggunaan media adalah untuk memudahkan belajar, bukan kemudahan mengajar, seperti pendapat Gagne bahwasannya media sebagai komponen sumber belajar yang dapat merangsang siswa untuk belajar. 
Pengelompokkan media yang sudah ada pada saat ini dapat memperjelas perbedaan tujuan penggunaan, fungsi dan kemampuannya, sehingga bisa dijadikan pedoman dalam memilih media yang sesuai untuk suatu pembelajaran tertentu.

Setiap jenis media memiliki karakteristiknya masing-masing yang khas, yang dikaitkan atau dilihat dari berbagai segi (misalnya dari segi ekonomisnya, lingkup sasaran yang dapat diliput, dan kemudahan kontrolnya oleh pemakai, menurut kemampuannya membangkitkan rangsangan seluruh alat indera, dan petunjuk penggunaannnya untuk mengatasi kondisi pembelajaran).

Gerlach dan Ely mengemukakan bahwa secara umum media pembelajaran memiliki tiga karakteristik atau ciri yaitu:

1) Ciri fiksatif, yang menggambarkan kemampuan media untuk merekam, menyimpan, melestarikan, dan mengkonstruksi suatu peristiwa atau obyek.

2) Ciri manipulatif, yaitu kemampuan media untuk mentransformasi suatu obyek, kejadian atau proses dalam mengatasi masalah ruang dan waktu.

3) Ciri distributif, yang menggambarkan kemampuan media mentransportasikan obyek atau kejadian melalui ruang dan secara bersamaan kejadian itu disajikan kepada sejumlah besar siswa, di berbagai tempat, dengan stimulus pengalaman yang relatif sama mengenai kejadian tersebut.

Selain itu, beberapa hal yang perlu diperhatikan di dalam penggunaan media yakni sebagai berikut:

1) Dasar teknologis, yakni penggunaan alat peraga didasarkan pada kemajuan dunia teknologi dewasa ini.

2) Dasar psikologis, bahwa manusia mempunyai tiga kemampuan yakni:

a) Kognitif ( pengetahuan intelektual) / knowledge

b) Afektif (nilai, sikap, perasaan)

c) Psikomotor ( ketrampilan kerja dengan koordinasi)

3) Dasar didaktis, penggunaan media hendaknya selaras dengan asas-asas didaktis, yakni: a) peragaan; b) minat; c) motivasi; d) kerja sendiri; e) kerja kelompok; f) lingkungan; g) individual; h) appersepsi; i) korelasi; j) ulangan.

Flashcards (kartu bergambar ) adalah semacam kartu pengingat atau kartu yang diperlihatkan sekilas kepada siswa. Ukurannya fleksibel tergantung dengan besar 
kecilnya kelas. Jika kelasnya berukuran sedang biasanya memakai ukuran 25 x $20 \mathrm{~cm}$. Kartu-kartu tersebut digambar atau ditulisi atau diberi tanda untuk memberikan petunjuk dan rangsangan bagi siswa berpikir atau melakukan sesuatu. ${ }^{7}$

Sedangkan klasifikasi media flashcards ini sebagai media visual (pandang. Media ini juga dapat dipakai baik untuk kelas besar, kecil maupun belajar secara individual.

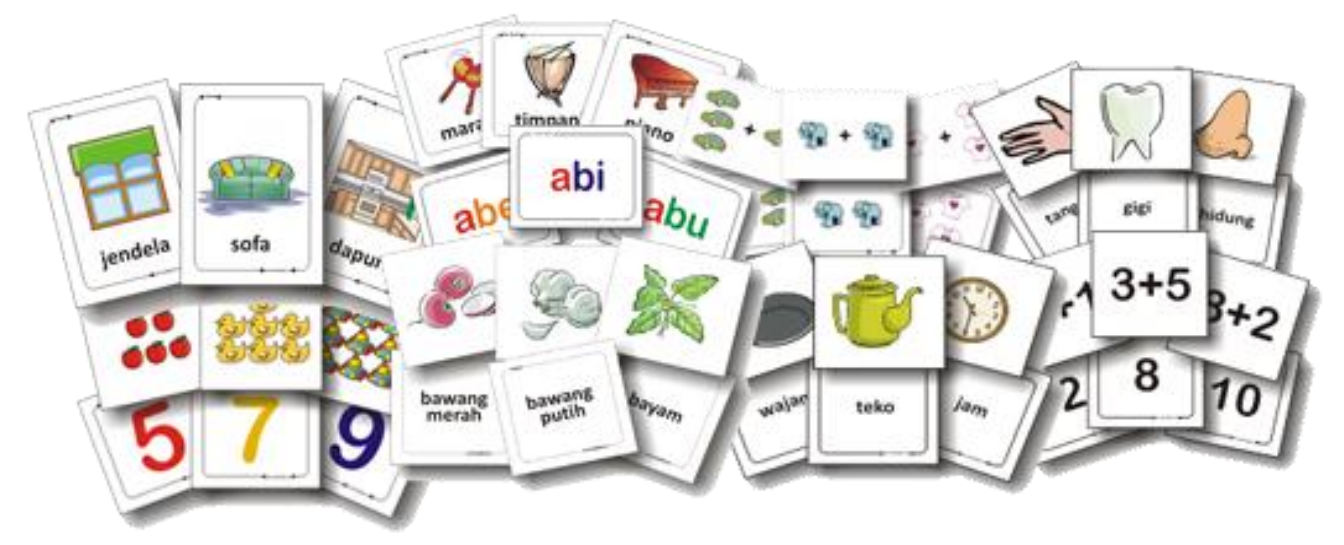

Flashcards adalah kartu-kartu bergambar yang dilengkapi kata-kata, yang diperkenalkan oleh Glenn Doman, seorang dokter ahli bedah otak dari Philadelphia, Pennsylvania. Gambar-gambar pada media flashcardsini dikelompok-kelompokkan antara lain: seri binatang, buah-buahan, pakaian, warna, bentuk-bentuk angka, dsb. Education flashcardstersebut dimainkan dengan cara diperlihatkan kepada siswa dan dibacakan secara cepat, hanya dalam waktu 1 detik untuk masing-masing kartu. Tujuan dari metode flashcards itu adalah melatih kemampuan otak kanan untuk mengingat gambar dan kata-kata, sehingga perbendaharaan kata dan kemampuan membaca siswa bisa dilatih dan ditingkatkan sejak usia dini dari education card. Flashcards ini merupakan terobosan baru di bidang flashcards baby education membaca dengan mendayagunakan kemampuan otak kanan untuk mengingat. Dasar dari flashcards adalah melatih siswa menghafal asosiasi antara gambar dan kata-kata, sehingga ketika ia melihat kata-kata itu lagi di kemudian hari maka ia akan mengingat dan dapat mengucapkannya.

Melalui mediaflashcards ini maka pembelajaran dapat diberikan kepada siswa sebagai sebuah permainan mengenal huruf dan kata-kata. Gambar-gambar yang menarik

${ }^{7}$ Azhar Arsyad, Bahasa Arab dan Metode Pengajarannya: Beberapa Pokok Pikiran (Yogyakarta: Pustaka Belajar. 2010), hal. 87 
dengan warna-warni menyolok akan disukai, sehingga guru dapat mengajak mereka bergembira, bermain dan belajar dengan media yang sederhana. ${ }^{8}$

Media ini sangat cocok didalam memahami kosakata bahasa Asing (bahasa Arab) baru yakni kata yang belum diketahui artinya sehingga harus dirubah terlebih dahulu menjadi bahasa otak, yaitu gambar. ${ }^{9}$

Alasan flashcard menjadi media pembelajaran yang sangat efektif dan menyenangkan adalah: ${ }^{10}$

1. Asosiasi yang kuat antara bagian depan dan belakang.

Bagian depan dan belakang kartu merupakan hubungan asosiasi yang kuat, baik hubungan sebab-akibat maupun yang lain. Eksklusivitas hubungan depan dan belakang ini akan menyebabkan daya tahan ingatan anak menjadi lebih lama.

2. Satu kartu $=$ satu ide.

Satu kartu flashcards hanya berisi satu permasalahan atau satu ide. Dengan media ini maka membantu dalam memecah-mecah permasalahan yang banyak menjadi terurai satu persatu tanpa kehilangan benang merahnya.

3. Manajemen otak.

Warna dan tips mengingatkannya menandakan kedua belah otak sudah terlibat secara aktif.

4. Mobilitas tinggi.

Flashcards mudah dibawa kemana-mana / fleksibel, kemudahan ini menyebabkan anak merasa nyaman belajar dimanapun berada.

5. Dapat dimainkan.

Media flashcards dapat dimainkan sambil belajar, baik sendiri maupun berkelompok. Contoh permainan adalah:

a. Tebak urut, dengan mengambil secara urut tumpukan kartu yang dipelajari kemudian menghitung flashcards yang dijawab tepat dan berapa yang kurang tepat.

b. Tebak acak, tebak pasangan, tebak pasangan acak.

\footnotetext{
${ }^{8}$ http://www.e-smartschool.com/ (diakses pada hari Rabu tanggal 25 Maret 2016)

${ }^{9}$ Susanto Windura, Memory Champion @ School, (Jakarta: PT Elex Media Komputindo, 2010), hal, 88.

${ }^{10} \mathrm{lbid}$, hal. 139.
} 


\section{c. Merry Go Ground.}

Metode Leitner (Leitner System) sebagai salahsatu cara efektif dalam menggunakan media flashcards, yakni dengan membagi tingkat kesulitan flashcards menjadi 2 bagian : sulit dan mudah. Kemudian siswa berusaha menjawab semua flashcards sesuai materi pelajaran dan bab yang dipelajari. Kemudian, flashcards yang dirasa sulit atau salah menjawabnya dapat dimasukkan ke bagian kotak yang sulit, begitu pula yang mudah. Setelah selesai satu putaran dimana seluruh flashcards sudah dicoba untuk diingat, maka putaran berikutnya siswa akan mencoba mengingat kembali seluruh flashcards dengan aturan flashcards yang ada dikotak sulit diulang lebih sering sampai siswa betul-betul mampu mengingat.

Selain cara yang telah dipaparkan diatas, media flashcards dapat pula dipadukan dengan buku catatan, yakni sebagai berikut:

a. Wajib membaca sumber asli yakni buku pelajaran yang dipelajari terlebih dahulu, kemudian menggunakan media flashcards.

b. Kemudian siswa membaca flashcards bagian depan terlebih dahulu, kemudian siswa harus dapat menjawab apa yang ditanyakan sesuai yang ada pada bagian belakangnya,

c. Siswa dapat menjawab atau menjelaskan lebih banyak dari apa yang tertera di halaman belakang flashcardstersebut.

d. Jika merasa kurang lengkap menjelaskannya, anak dapat melihat kembali buku catatan atau buku pelajaran sekolah untuk melengkapinya.

e. Setelah menjawab atau menerangkan, anak dapat melihat halaman belakangnya untuk mencocokkan atau mengetahui apakah jawabannya benar atau salah.

f. Sesekali beri siswa jeda baik dengan istirahat atau berganti dengan flashcards subjek lain.

g. Jika terdapat informasi penting di buku catatan atau pelajaran sekolah yang belum dibuat flashcardsnya, maka dapat segera ditambah dengan membuatflashcards yang baru.

h. Setelah menggunakan flashcards, siswa wajib menutupnya dengan latihan soal yang ada di buku catatan atau cetak. 
i. Melakukan pengulangan untuk mendapatkan efek ingatan jangka panjang yang permanen.

\section{PENUTUP}

Berdasarkan pemaparan di atas dapat disimpulkan bahwa media flashcards sangat efektif dalam meningkatkan perbendaharaan kosakata bahasa Arab siswa. Hal ini dapat dibuktikan bahwa media flashcards mempunyai beberapa kelebihan antara lain adalah media ini sangat cocok didalam memahami kosakata bahasa Asing (bahasa Arab) baru yakni kata yang belum diketahui artinya sehingga harus dirubah terlebih dahulu menjadi bahasa otak, yaitu gambar.

\section{DAFTAR PUSTAKA}

Abdul Hamid, dkk. 2010. Pembelajaran bahasa Arab: Matode, Strategi, Materi, dan Media. Malang: UIN Malang Press.

Amir Daien Indrakusuma. 1973. Pengantar Ilmu Pendidikan. Surabaya: Usaha Nasional.

Arif S. Sadirman. 1990. Media pendidikan : pengertian, pengembangan, dan pemanfaatannya, Jakarta: Rajawali.

Aswan Zain dan Syaiful Bahri Djamarah. 1995. Strategi Belajar mengajar. Jakarta : PT Rineka Cipta.

Azhar Arsyad. 2010. Bahasa Arab dan Metode Pengajarannya: Beberapa Pokok Pikiran Yogyakarta: Pustaka Belajar.

Hendyat Soetopo. 2005.Pendidikan Dan Pembelajaran, Teori, Permasalahan, Dan Praktek. Malang: UMM Press.

Susanto Windura. 2010. Memory Champion @ School. Jakarta: PT Elex Media Komputindo.

Syamsuddin Asyrofi, dkk.2006.Metodologi Pembelajaran bahasa Arab. Yogyakarta: Pokja Akademik.

http://www.e-smartschool.com/ (diakses pada hari Rabu tanggal 25 Maret 2016) 